\title{
Adsorption Separation of Nickel from Wastewater by using Olive Stones
}

\author{
Abdel-Moneum Ahmed a, Alaa Ali ${ }^{\mathrm{b}}$, Ahmed Hosny Ghazy b,*
}

\section{A R T I C L E I N F O \\ Received: 20 November 2018 \\ Revised: 11 December 2018 \\ Accepted: 29 December \\ Available online: 6 January 2019}

\section{K E Y W O R D S}

Wastewater

Nickel

Activated carbon olive stone

Removal

\section{A B S T RA C T}

In this study, the adsorption potential of activated carbon olive stone for removal of $\mathrm{Ni}^{2+}$ ions from wastewater has been investigated. The study involves batch type experiments to investigate the effect of initial concentration, adsorbent dose, agitation speed, contact time, temperature and $\mathrm{pH}$ of solution on adsorption process. The optimum conditions were evaluated. The adsorption process has fit pseudo-second order kinetic models. Langmuir and Freundlich adsorption isotherm models were applied to analyze adsorption data and both were found to be applicable to this adsorption process. Thermodynamic parameters, e.g., $\Delta G^{\circ}, \Delta S^{\circ}$ and $\Delta \mathrm{H}^{\circ}$ of the on-going adsorption process have also been calculated and the sorption process was found to be endothermic. Finally, it can be seen that the activated carbon olive stone was found to be more effective for the removal of $\mathrm{Ni}^{2+}$ from waste water than any other adsorbent.

GRA P H I CAL ABSTRACT

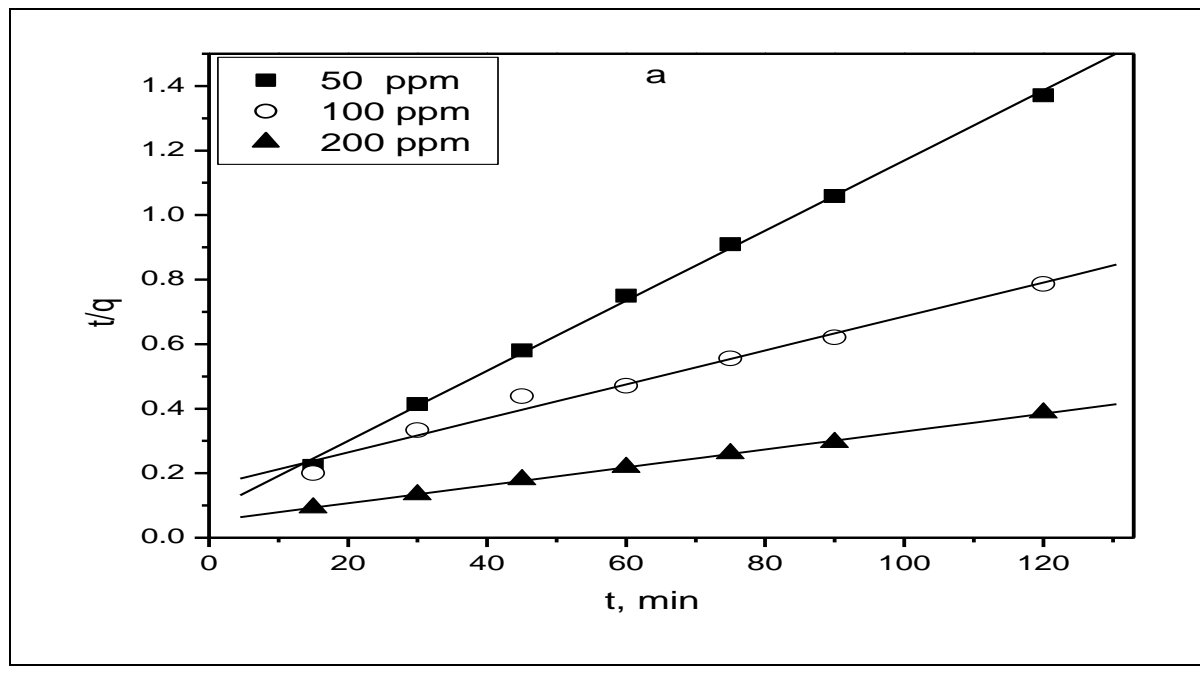

*Corresponding author's E-mail address: ahmedhosny @ sci.dmu.edu.eg, Tel.: 001090230025

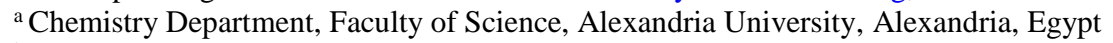

${ }^{\mathrm{b}}$ Chemistry Department, Faculty of Science, Damnhour University, Alexandria, Egypt 


\section{Introduction}

Industrial effluents are the major sources for contamination of water resources by heavy metals. $\mathrm{Ni}^{2+}$ belongs to the socalled « essential »metals and is identified as a component in a number of enzymes, participating in important metabolic reactions, such as ureolysis, hydrogen metabolism, methane biogenesis, and acidogenesis [1]. But, $\mathrm{Ni}^{2+}$ ion intake over the permissible levels results in different types of disease such as pulmonary fibrosis, renal edema, skin dermatitis, and gastrointestinal distress (e.g., nausea, vomiting, diarrhea) [1]. It is, therefore, essential to remove $\mathrm{Ni}^{2+}$ from wastewater before disposal. Mining and metallurgy of nickel, stainless steel, aircraft industries, nickel electroplating, battery and manufacturing, pigments and ceramic industries wastewaters contain high amounts of nickel ions [2]. The commonly used techniques for removing metal ions from effluent include ion exchange, adsorption, chemical precipitation, reserve osmosis and solvent extraction [3-5]. These techniques are economically expensive and have disadvantages like incomplete metal removal, generation of toxic sludge and other disposable waste product. Recovery of heavy metals from wastewaters and industrial wastes has become a very important environmental issue. Nickel has many useful applications in our life and is harmful if discharged into natural water resources [6]. $\mathrm{Ni}^{2+}$ is present in the effluents of silver refineries, electroplating, zinc base casting and storage battery industries. The acceptable limit of $\mathrm{Ni}$ in drinking water is $0.01 \mathrm{mgL}^{-1}$ and for discharge of industrial wastewater is $2.0 \mathrm{mgL}^{-1}$ [7]. At higher concentrations, $\mathrm{Ni}^{2+}$ causes cancer of lungs, nose and bone. Dermatitis (Ni itch) is the most frequent effect of exposure to $\mathrm{Ni}$, such as coins and costume jewellery. Ni carbonyl $\left[\mathrm{Ni}(\mathrm{CO})_{4}\right]$ has been estimated as lethal in humans at atmospheric exposures of 30 ppm for 30 min [8]. Acute poisoning of $\mathrm{Ni}^{2+}$ causes headache, dizziness, nausea and vomiting, chest pain, tightness of the chest, dry cough and shortness of breath, rapid respiration, cyanosis and extreme weakness [9].

Hence, it is essential to remove $\mathrm{Ni}^{2+}$ from industrial wastewater before being mixed with natural water sources. In advanced countries, removal of $\mathrm{Ni}^{2+}$ metal ions in wastewater is normally achieved by advanced technologies such as precipitation-filtration, ion exchange and membrane separation [10]. However, in developing countries, these treatments cannot be applied because of technical levels and insufficient funds. Therefore, it is desired that the simple and economical removal method which can utilize in 
developing countries is established. Experimental

Although, the treatment cost for precipitation-filtration method is comparatively cheap, the treatment procedure is complicated. On the other hand, adsorption method such as ion exchange and membrane separation is simple one for the removal of heavy metals. However, there is a limit in the generality in developing countries because chelating and ion-exchange resins are expensive. In the present study, removal of $\mathrm{Ni}^{2+}$ ions from wastewater was further carried out by adsorption onto activated carbon olive stone.

The objectives of the present study are: 1 ) to study the effect of contact time on $\mathrm{Ni}^{2+}$ ions adsorption onto activated carbon; 2) to investigate the influence of $\mathrm{pH}$ on the adsorption of $\mathrm{Ni}^{2+}$ ions; 3 ) to study the adsorption of $\mathrm{Ni}^{2+}$ ions at different temperatures and to calculate the adsorption thermodynamic parameters (i.e., $\Delta \mathrm{H}^{\circ}, \Delta \mathrm{S}^{\circ}$ and $\Delta \mathrm{G}^{\circ}$ ); 4) to find the effect of adsorbent dose and initial concentration on the adsorption of $\mathrm{Ni}^{2+}$ ions; 5 ) to describe the experimental data of adsorption isotherms through Langmuir and Freundlich models; 6) to discuss the adsorption mechanism of $\mathrm{Ni}^{2+}$ ions onto both adsorbents.

\section{Material and Method}

A stock solution of nickel of a concentration $1000 \mathrm{mg} / \mathrm{L}$ was prepared by dissolving $4.3103 \mathrm{mg}$ of nickel sulphate in $1000 \mathrm{~mL}$ distilled water .The solution was diluted from $1000 \mathrm{mg} / \mathrm{I}$ to 50,100,200,300 and 400 ppm using the dilution law.

\section{Bio-sorption}

It is a special kind of adsorption activated carbon and zeolite in which natural bio materials are used as adsorbents. In this work, will be used as a natural bio-sorbent. Activated carbon olive stone and Zeolite is an examples of the non-metabolic mechanism in which a physico-chemical interaction between function groups on the surface of the adsorbent and heavy metals. Bio-sorption of heavy metals has been considered as an alternative cost-effective method for the treatment of these wastewaters. Bio-sorption has been defined as the property of certain biomolecules (or types of biomass) to bind and concentrate selected ions or other molecules from aqueous solutions.

The olive stone was washed with hot distilled water to remove water soluble impurities and dried in an oven at $150{ }^{\circ} \mathrm{C}$ until dry. Finally it was ground and sieved to 170-200 mesh before utilizing it is as olive stone. 


\section{Apparatus and instrumentation}

Magnetic hot plate stirrer was used to stir the heavy metals ions solutions with adsorbents (activated carbon). A definite volume of heavy metal ions solution with a known initial ions concentration was stirred with a definite amount of adsorbents for a certain time at fixed temperature and agitation rate. The $\mathrm{pH}$ values of the solution were measured by digital $\mathrm{pH}$ meter (Model $\mu \mathrm{pH}$ system-361, India). The metals ions concentrations were measured by using atomic-absorption spectrophotometer, AAS, (Model, AA55; Varian Inc., USA).

\section{Experimental procedures}

$\mathrm{Ni}^{2+}$ sulfate $\left(\mathrm{NiSO}_{4}\right)$ and redistilled water were used to prepare stock solutions with a concentration of $1000 \mathrm{ppm}$ of the $\mathrm{Ni}^{2+}$ and were diluted for preparing test solutions. Several solutions with different initial concentrations of nickel chloride $(50,100$, 200, 300 and $400 \mathrm{ppm}$ ) were prepared. Adjustment of pH was carried out by using $0.1 \mathrm{~N} \mathrm{NaOH}$ and/ or $0.1 \mathrm{~N} \mathrm{HCl}$. All experiments conditions were optimized to achieve maximum removal efficiency (RE) for all heavy metals ions by adding different amounts of adsorbent $(0.1,0.3,0.5,0.7$ and $1.0 \mathrm{~g}$ ) to different concentrations of $250 \mathrm{~mL}$ of heavy metal ions solution. The agitation rate for all experiments was $200 \mathrm{rpm}$ and the residence time was $(0,15,30,45,60,75$,
90 and $120 \mathrm{~min}$ ) at $25^{\circ} \mathrm{C}$.

$1 \mathrm{~mL}$ of Sample was taken from each reaction solution and diluted to $10 \mathrm{~mL}$ by redistilled water, adsorbents were then separated from the solution by using filter paper [11] and the residual $\mathrm{Ni}^{2+}$ ions concentrations in the each solution was then determined by atomic-absorption spectrophotometer (AAS). The effects of several parameters, such as contact time, initial concentration, adsorbent dose, solution volume, $\mathrm{pH}$ value and temperature on the adsorption of $\mathrm{Ni}^{2+}$ ions onto activated carbon were studied.

\section{Data analysis}

The uptake of $\mathrm{Ni}^{2+}$ ions were calculated from the mass balance, which was stated as the amount of solute adsorbed onto the solid. It equals the amount of solute removed from the solution. Mathematically, it can be expressed by Eq. (1):

$\mathrm{qe}=(\mathrm{Ci}-\mathrm{Ce}) / \mathrm{S}$

where:

qe the heavy metal ions concentration adsorbed by an adsorbent at equilibrium (mg of metal ions/g of adsorbent).

$\mathrm{Ci}$ is the initial concentration of metal ions in the solution $(\mathrm{mg} / \mathrm{L})$.

Ce is the equilibrium concentration or final concentration of metal ions in the solution (mg/L). 
$S$ the dosage concentration and it is expressed by Eq. (2):

$\mathrm{S}=\mathrm{m} / \mathrm{V}$

where $\mathrm{V}$ is the initial volume of metal ions solution used (L) and $m$ is the weight of dried used adsorbent (g).

The percentage of adsorption (\%) is calculated using Eq. (3):

$\%$ adsorption $=[(\mathrm{Ci}-\mathrm{Ce}) / \mathrm{Ci}] \times 100$

\section{Adsorption kinetics}

To investigate the mechanism of $\mathrm{Ni}^{2+}$ ions adsorption onto activated carbon, two kinetic models were considered as follows:

Largergren pseudo-first order model can expressed by Eqs. (4) and (5):

$\mathrm{dq} / \mathrm{dt}=\mathrm{k} 1(\mathrm{qe}-\mathrm{q})$

$\ln (\mathrm{qe}-\mathrm{q})=\ln \mathrm{qe}-\mathrm{k} 1 \mathrm{t}$

The pseudo-second order model is given by Eqs. (6) and (7):

$\mathrm{dq} / \mathrm{dt}=\mathrm{k} 2(\mathrm{qe}-\mathrm{q}) 2$

$\mathrm{t} / \mathrm{q}=\mathrm{t} / \mathrm{qe}+1 / \mathrm{k} 2 \mathrm{qe} 2$

where $\mathrm{q}$ and qe are the amount of $\mathrm{Ni}^{2+}$ metal adsorbed per unit weight of adsorbent $(\mathrm{mg} / \mathrm{g})$ at time $\mathrm{t}$ and at equilibrium, respectively, and $\mathrm{k}_{1}$ and $\mathrm{k}_{2}$ are the adsorption rate constants. The applicability of the above two models can be examined by each linear plot of $\ln (\mathrm{qe}-\mathrm{q})$ vs. $\mathrm{t}$, and (t/q) vs. $t$, respectively and are represented in Figure
1 respectively. The kinetics study for the adsorption of $\mathrm{Ni}^{2+}$ was conducted at optimum pH 5.0 and completed in $2 \mathrm{~h}$ for the concentrations $(50,100$ and $200 \mathrm{mg} / \mathrm{L}) \mathrm{Ni}^{2+}$ ions onto $(0.1,0.3,0.5,0.7$ and $1.0 \mathrm{~g} / 250$ $\mathrm{mL}$ ) doses of both adsorbents at $25{ }^{\circ} \mathrm{C}$. The validity of the kinetic models is tested by the magnitude of the regression coefficient $R_{2}$, given in Table 1. It is important to note that for a pseudo-first order, the correlation coefficient is always less than 0.98 , which is indicative of a bad correlation. In contrast, the application of a pseudo-second order model leads to much better regression coefficients, all greater than 0.99. Moreover, from Table 1 and Figures 1-2, the qe, the values estimated from the pseudo-first kinetic model gave significantly different values compared to experimental values and the correlation coefficients were also found to be lower. However, in pseudo-second order kinetic model the calculated qe, the values are very close to qe, exp values at various initial concentrations and various adsorbent doses.

For the pseudo-second order kinetic model, the rate constant decreases with an increasing of initial $\mathrm{Ni}^{2+}$ concentration.

Parameters affecting adsorption process:

\section{Effect of contact time}

The effect of contact time for five different concentrations of $\mathrm{Ni}^{2+}(50,100,200,300$ and 
$400 \mathrm{mg} / \mathrm{L})$ onto $(0.1,0.3,0.5,0.7$ and 1.0

$\mathrm{g} / 250 \mathrm{~mL}$ ) of activated carbon doses , pH 5.0

at $25^{\circ} \mathrm{C}$ is shown in Figure 2 .

The $\mathrm{Ni}^{2+}$ percentage removal increased by time until the equilibrium is attained between the amounts of $\mathrm{Ni}^{2+}$ adsorbed onto both adsorbents and the remaining in solution.

The Figures showed that the adsorption of $\mathrm{Ni}^{2+}$ increased with time from 0 to 30 min and more and then increased slowly up to the end of experiment.

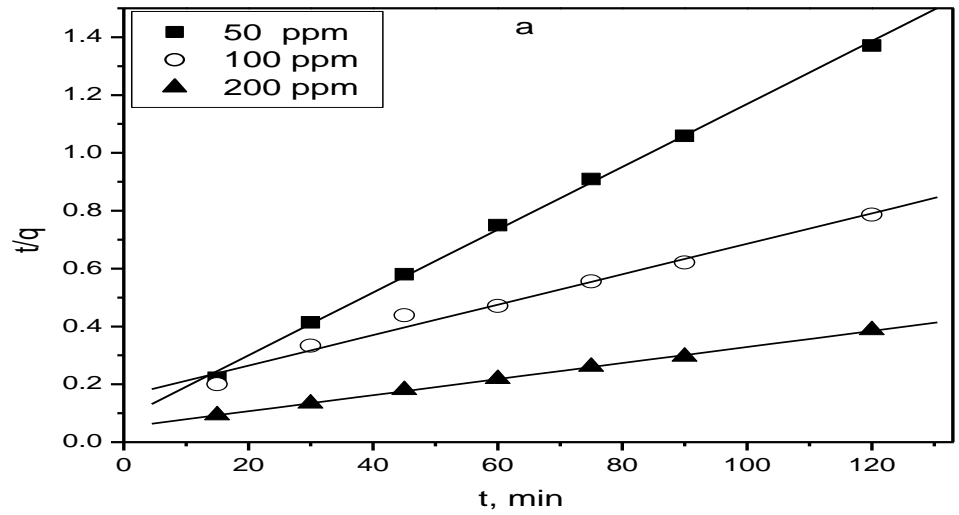

Figure 1. Pseudo-second order kinetic plots for the adsorption of different initial concentrations: $50(\mathbf{\square}), 100(\mathrm{O})$ and $200(\boldsymbol{\Delta}) \mathrm{ppm} \mathrm{Ni}^{2+}$ ions onto different adsorbent doses of activated carbon:a) 0.1 g/250 $\mathrm{mL},\left(\mathrm{pH}\right.$ : 5.0; agitation speed: $200 \mathrm{rpm}$; temperature: $25^{\circ} \mathrm{C}$ )

Table 1. The adsorption kinetics model rate constants for adsorption of $\mathrm{Ni}^{2+}$ ions onto activated carbon at various concentrations and constant temperature $25^{\circ} \mathrm{C}$

\begin{tabular}{|c|c|c|c|c|c|c|c|c|}
\hline Adsorbent & $\begin{array}{c}\text { Co } \\
\text { (mg/L) }\end{array}$ & $\begin{array}{l}\text { qe exp. } \\
\text { (mg/g) }\end{array}$ & $\begin{array}{c}K_{1} \\
(\min -1)\end{array}$ & $\begin{array}{c}\text { Lagergren } \\
\text { first } \\
\text { order } \\
\text { q1, theo. } \\
\text { (mg/g) }\end{array}$ & $\mathbf{R}^{2}$ & 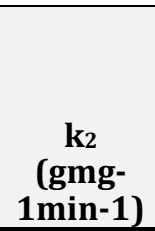 & $\begin{array}{c}\text { Pseudo- } \\
\text { second } \\
\text { order } \\
\text { q2, theo. } \\
\text { (mg/g) }\end{array}$ & $\mathbf{R}^{2}$ \\
\hline \multirow{3}{*}{$\begin{array}{l}\text { Activated } \\
\text { Carbon(0.1 } \\
\text { g) }\end{array}$} & 50 & 87.5 & $\begin{array}{c}3.4 \times 10- \\
2\end{array}$ & 52 & 0.883 & $1.4 \times 10-3$ & 88 & 0.998 \\
\hline & 100 & 152.5 & $\begin{array}{c}2.7 \times 10 \\
2\end{array}$ & 141 & 0.971 & $1.7 \times 10-4$ & 150 & 0.993 \\
\hline & 200 & 310 & $\begin{array}{c}3.3 \times 10- \\
2\end{array}$ & 268 & 0.988 & $1.5 \times 10-4$ & 308 & 0.998 \\
\hline \multirow{3}{*}{$\begin{array}{l}\text { Activated } \\
\text { Carbon( } 0.5 \\
\text { g) }\end{array}$} & 50 & 19 & $\begin{array}{c}2.9 \times 10- \\
2\end{array}$ & 11 & 0.812 & $8.5 \times 10-3$ & 20 & 0.993 \\
\hline & 100 & 34 & $\begin{array}{c}3.3 \times 10- \\
2\end{array}$ & 26 & 0.970 & $2.2 \times 10-3$ & 32 & 0.996 \\
\hline & 200 & 64 & $\begin{array}{c}3.4 \times 10- \\
2\end{array}$ & 45 & 0.935 & $1.9 \times 10-4$ & 61 & 0.998 \\
\hline
\end{tabular}


It can be concluded that the rate of $\mathrm{Ni}^{2+}$ binding with activated carbon is more at initial stages, which gradually decreases and becomes almost constant after an optimum period $90 \mathrm{~min}$.

Figure 3 shows the relation between the amount of adsorbed ions per gram of adsorbent and contact time in the presence of different amounts of adsorbent at $25{ }^{\circ} \mathrm{C}$. At the begin, $q$ raises rapidly and by time it increases slowly till the maximum adsorption.

\section{Effect of adsorbent dose}

The effect of adsorbent dose on percentage removal of $(50,100,200,300$ and $400 \mathrm{mg} / \mathrm{L})$ $\mathrm{Ni}^{2+}$ ions concentrations at $25^{\circ} \mathrm{C}$ is shown in Figure 4. Percentage of $\mathrm{Ni}^{2+}$ ions removal increased when the adsorbent dose increased from 0.1 to $1.0 \mathrm{~g} / 250 \mathrm{~mL}$ for activated carbon. It can be seen that, the number of adsorption sites or surface area increases with the weight of adsorbent and hence results in a higher percent of metal ions removal at a high dose. However, the amount of metal ions adsorbed per unit weight of adsorbent (q) decreases with the adsorbent dose. This is due to the fact that at higher adsorbent dose the solutions ion concentration drops to a lower value and the system reaches equilibrium at lower values of $\mathrm{q}$ indicating the adsorption sites remain unsaturated.

\section{Effect of initial $\mathrm{Ni}^{2+}$ ions concentration}

An increase of initial $\mathrm{Ni}^{2+}$ concentration from 50 to $300 \mathrm{mg} / \mathrm{L}$ with different amounts of activated carbon $(0.1,0.3,0.5,0.7$ and 1.0 $\mathrm{g} / 250 \mathrm{~mL}$ ) when other experimental conditions are kept constant, illustrated in Figure 5. It can be seen from the figures that, $\%$ removal of $\mathrm{Ni}^{2+}$ increases when the initial concentration decreased. At low ions concentrations the ratio of surface active sites to the total metal ions in the solution is high and hence all metal ions may interact with the adsorbent and be removed from the solution. However, amount of metal adsorbed per unit weight of adsorbent, q, is higher at high concentration as shown in Figure 5.

\section{Effect of pH on the uptake of $\mathrm{Ni}^{2+}$}

The $\mathrm{pH}$ value of the solution is an important controlling parameter in the adsorption process, and the initial $\mathrm{pH}$ value of the solution has more influence than the final $\mathrm{pH}$, which influences both the adsorbent surface metal binding sites and the metal chemistry in water [11]. Hence, the influence of $\mathrm{pH}$ on the adsorption of $\mathrm{Ni}^{2+}$ onto activated carbon was examined in the range of 2-9, the results are shown in Figure 6 . The figures show that, the sorption of $\mathrm{Ni}^{2+}$ increases with increasing $\mathrm{pH}$ at $\mathrm{pH} 2-7$, then increases sharply with increasing $\mathrm{pH}$ at $\mathrm{pH}$ $>7$ and at last maintains a high level at 
$\mathrm{pH}>8.5$. The abrupt increase of $\mathrm{Ni}^{2+}$ sorption may be attributed to the surface precipitation of $\mathrm{Ni}(\mathrm{OH})_{2}$ (S) onto both activated carbon. It is well known that $\mathrm{Ni}^{2+}$ can easily form precipitation because of the low solubility of $\mathrm{Ni}(\mathrm{OH})_{2}\left(\mathrm{~K}_{\mathrm{sp}}=2.0 \times 10-15\right)$. It is clear that $\mathrm{Ni}^{2+}$ ions start to form precipitation at $\mathrm{pH} \sim 8.6$. However, one can see that more than $90 \% \mathrm{Ni}^{2+}$ has been adsorbed to activated carbon at $\mathrm{pH}>8.6$.

\section{Effect of temperature}

The effect of the temperature on the efficiency of adsorption of $\mathrm{Ni}^{2+}$ was studied at different temperatures in the range of 25 $40{ }^{\circ} \mathrm{C}$. The adsorption experiments were carried out with $(50,100,200,300$ and 400 $\mathrm{mg} / \mathrm{L}$ ) initial concentrations of $\mathrm{Ni}^{2+}$ onto 0.5 $\mathrm{g} / 250 \mathrm{~mL}$ for both activated carbon at $\mathrm{pH}$ 5.0. The adsorption of $\mathrm{Ni}^{2+}$ onto both adsorbents increases by an increased temperature from 25 to $40{ }^{\circ} \mathrm{C}$ Figure 6 , this indicates that the $\mathrm{Ni}^{2+}$ uptake by adsorption onto activated carbon at higher temperature. This may be due to the availability of more active sites of both adsorbent at higher temperature.

\section{Adsorption isotherm}

Adsorption isotherm is an expression that shows the relationship between the amount of adsorbate adsorbed per unit weight of adsorbed (qe, mg/g) and the concentration of adsorbate in bulk solution (Ce, $\mathrm{mg} / \mathrm{L}$ ) at given temperature under equilibrium conditions. Adsorption equilibrium is established when the amount of adsorbate being adsorbed is equal to the amount being desorbed from the adsorbent.

At this stage, the equilibrium concentrations in both phases are constant.

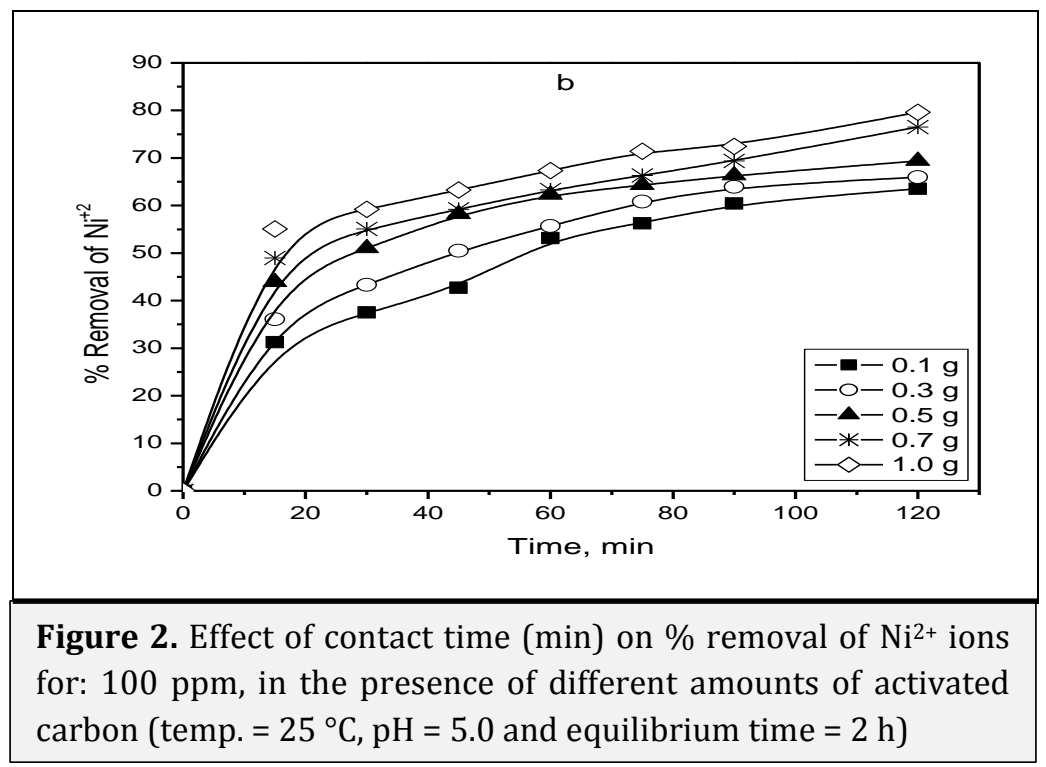




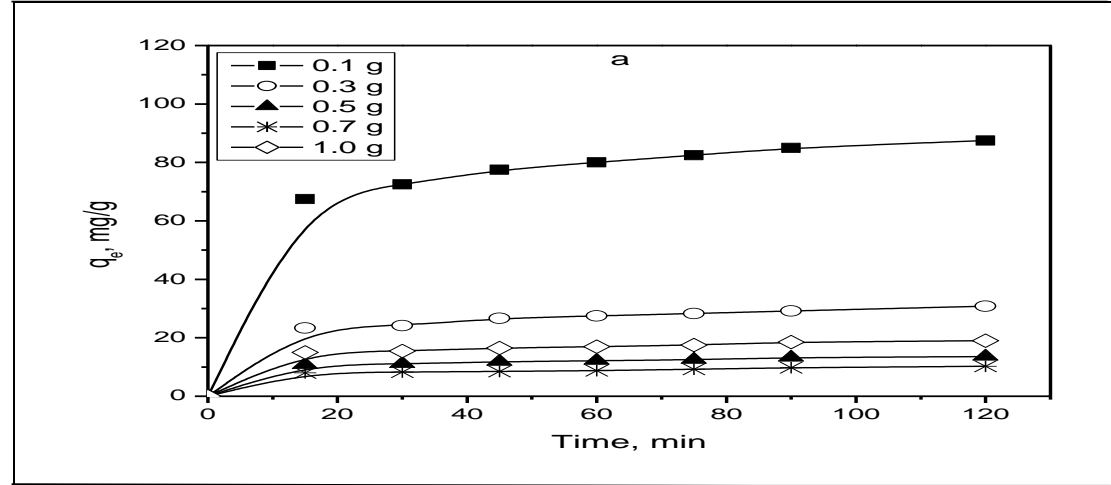

Figure 3. Effect of contact time on adsorbed amount of $\mathrm{Ni}^{2+}$ for different concentrations: a) $50 \mathrm{ppm}$ and b) $100 \mathrm{ppm}$, in the presence of different $h$ )

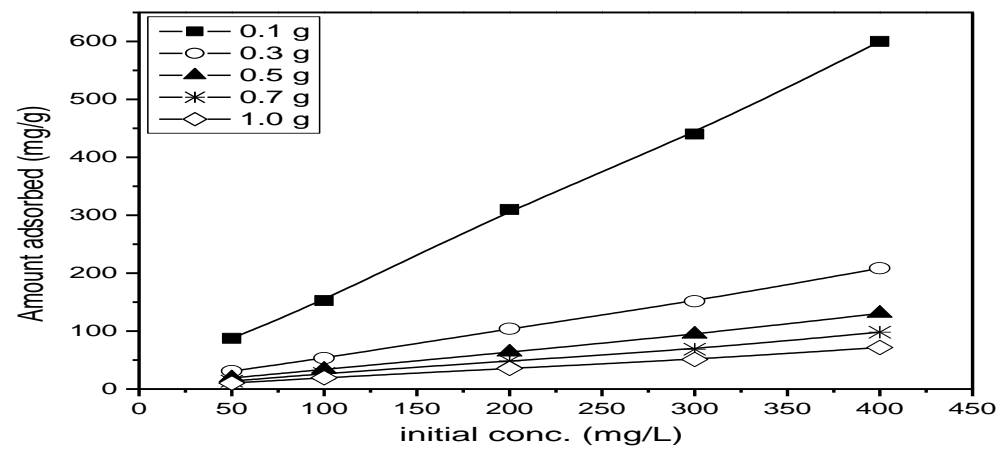

Figure 4. The effect of initial concentration (namely 50, 100, 200 and $300 \mathrm{mg} / \mathrm{L}$ ) on quantity adsorbed of $\mathrm{Ni}^{2+}$ ions in the presence of different amounts of activated carbon (temp. $=25^{\circ} \mathrm{C}, \mathrm{pH}=5.0$ and equilibrium time $=2 \mathrm{~h}$ )

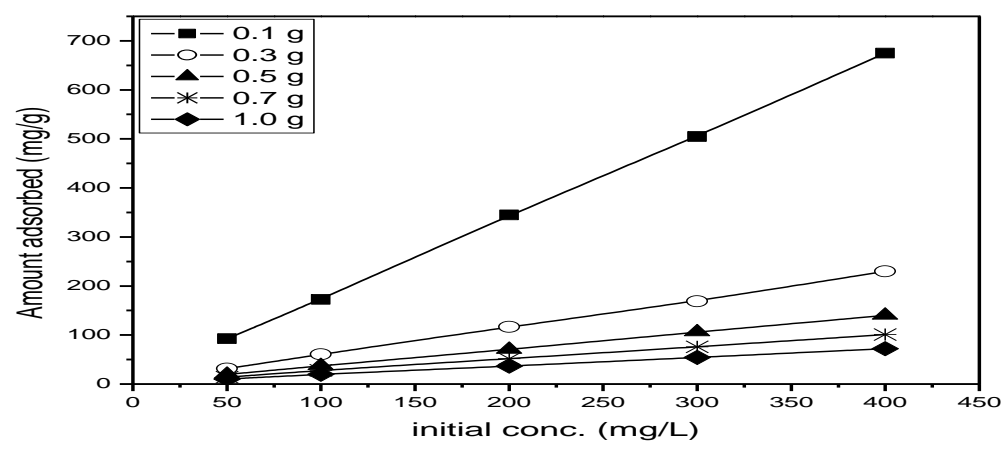

Figure 5. The effect of initial concentration (namely 50, 100, 200 and 300 $\mathrm{mg} / \mathrm{L}$ ) on quantity adsorbed of $\mathrm{Ni}^{2+}$ ions (temp. $=25^{\circ} \mathrm{C}, \mathrm{pH}=5.0$ and equilibrium time $=2 \mathrm{~h}$ ) 


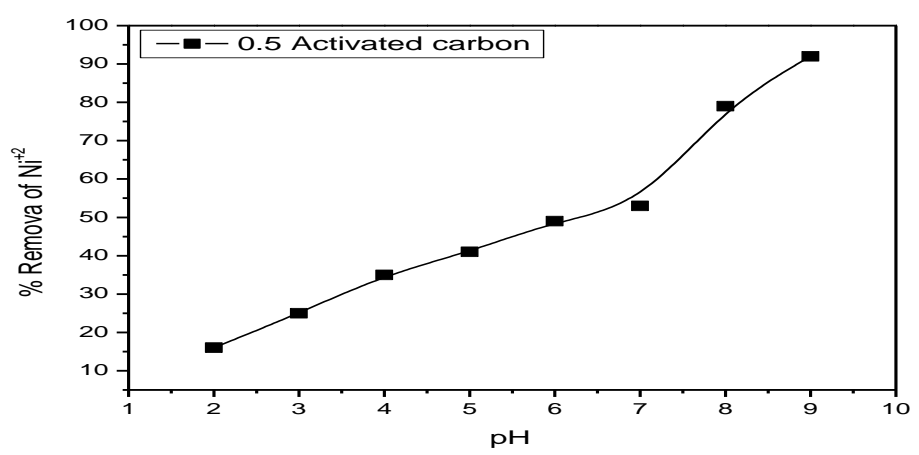

Figure 6. Effect of $\mathrm{pH}$ for the adsorption of $\mathrm{Ni}^{2+}$ ions onto activated carbon (conditions; $\mathrm{Ni}^{2+}$ ions initial concentration: $100 \mathrm{mg} / \mathrm{L}$; adsorbent dose: $0.5 \mathrm{~g} / 250 \mathrm{~mL}$; agitation speed: $200 \mathrm{rpm}$; contact time: $2 \mathrm{~h}$ ) at $25^{\circ} \mathrm{C}$

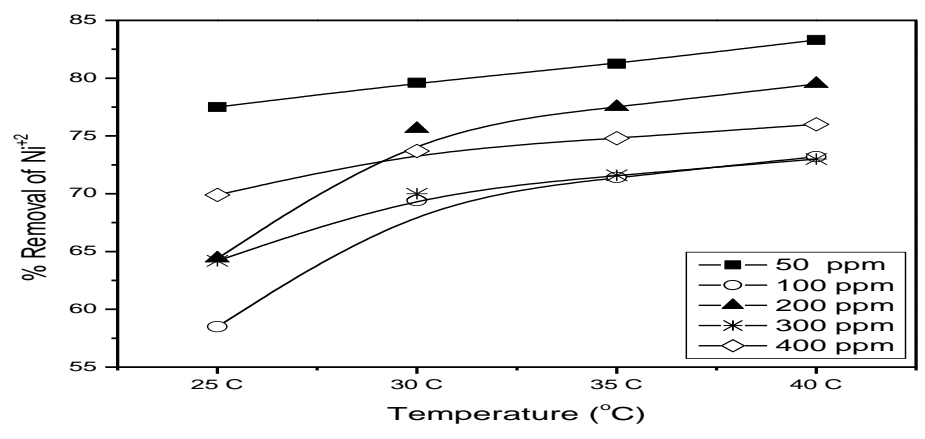

Figure 7. The effect of temperature between 25 and $40^{\circ} \mathrm{C}$ for the $\%$ removal of different initial $\mathrm{Ni}^{2+}$ ions concentrations onto activated carbon (conditions; pH: 5.0; adsorbent dose: 0.5 g/250 $\mathrm{mL}$; agitation speed: $200 \mathrm{rpm}$; contact time: $2 \mathrm{~h}$ )

Adsorption isotherm is very useful in giving information about adsorption mechanisms, surface properties and affinity of an adsorbent towards heavy metals ions [12]. The isotherm data were further analyzed with two most common isotherm models:

The Langmuir and Freundlich models (Langmuir, 1916; Freundlich, 1906), are the most frequently employed to describe equilibrium for the adsorption of $(50,100$ and $200 \mathrm{mg} / \mathrm{L}$ ) $\mathrm{Ni}^{2+}$ ions concentrations onto $(0.1,0.3,0.5,0.7$, and $1.0 \mathrm{~g} / 250 \mathrm{~mL})$ for activated carbon at $25{ }^{\circ} \mathrm{C}$. The Langmuir isotherm is probably the most widely applied isotherm model in many adsorption studies. The model was developed based on assumptions that adsorption occurs at specific homogeneous sites on the adsorbent and was used successfully in many monolayer adsorption processes. It 
also assumes no transmigration of adsorbate in the plane of adsorbent surface. The Langmuir isotherm for adsorption can be obtained from Eq. (8):

$$
\mathrm{Ce} / \mathrm{qe}=1 /\left(\mathrm{q}_{\max } \mathrm{b}\right)+\left(1 / \mathrm{q}_{\max }\right) \mathrm{Ce}
$$

Where $\mathrm{q}_{\max }$ is the maximum metal ions uptake per unit mass of adsorbent (mg/g), which is related to the adsorption capacity and $\mathrm{b}$ is Langmuir constant $(\mathrm{L} / \mathrm{mol})$ which is exponentially proportional to the heat of adsorption and related to the adsorption intensity. Therefore, a plot of Ce/qe versus Ce gives a straight line of the slop $1 / \mathrm{q}_{\max }$ and intercept 1/( $\left.q_{\max } b\right)$ as shown in Figures 8, 9. Freundlich isotherm gives the relationship between equilibrium liquid and solid phase capacity based on the multilayer adsorption (heterogeneous surface). This isotherm is derived from the assumption that the adsorption sites are distributed exponentially with respect to the heat of adsorption. It also assumes that the stronger adsorption sites are occupied first and the binding strength decreases with the increasing degree of site occupation. The Freundlich model is given by (Freundlich, 1906) the classical empirical isotherm, Eq. (9):

$\operatorname{lnqe}=\ln \mathrm{KF}+1 / \mathrm{n} \ln \mathrm{Ce}$

The Freundlich adsorption isotherm is an indicator of the extent of heterogeneity of the adsorbent surface, where the Freundlich constants $\mathrm{K}_{\mathrm{F}}$ and $\mathrm{n}$, which respectively indicating the adsorption capacity and the adsorption intensity, were calculated from the intercept and slope of the plot of $\ln$ qe versus $\ln$ Ce as shown in Figures 8, 9.

This Freundlich type behaviour is indicative of surface heterogeneity of the adsorbents, i.e., the adsorptive sites (surface of activated carbon) are made up of small heterogeneous adsorption patches that are homogeneous in themselves. The activation of adsorption sites takes place, leading to increased adsorption probably through the surface exchange mechanism.

The calculated results of Langmuir and Freundlich isotherm constants are given in Table 2. It can be seen that, the Freundlich model yields a much better fit than the Langmuir model, when the correlation coefficient $\left(\mathrm{R}^{2}\right)$ values are compared in Table $2\left(\mathrm{R}^{2}\right.$ values of Freundlich plot $>0.99$ was close to unity, indicating isotherm data fitted well to Freundlich model). The Freundlich constant $\left(\mathrm{K}_{\mathrm{F}}\right)$ indicates the sorption capacity of the sorbent. From Table 8 , It is noted that the values of ( $n$ ) are bigger than 1 , reflecting the favourable adsorption. The plots of (qe) versus (Ce) are presented in Figures 8, 9, it is seen that (qe) increased by increasing (Ce) with higher slope at the initial stages which indicates that, initially, there are 
numerous readily accessible sites for adsorption processes. Eventually (qe) reaches maximum value at higher $(\mathrm{Ce})$, indicating that the adsorption is saturated at this level.
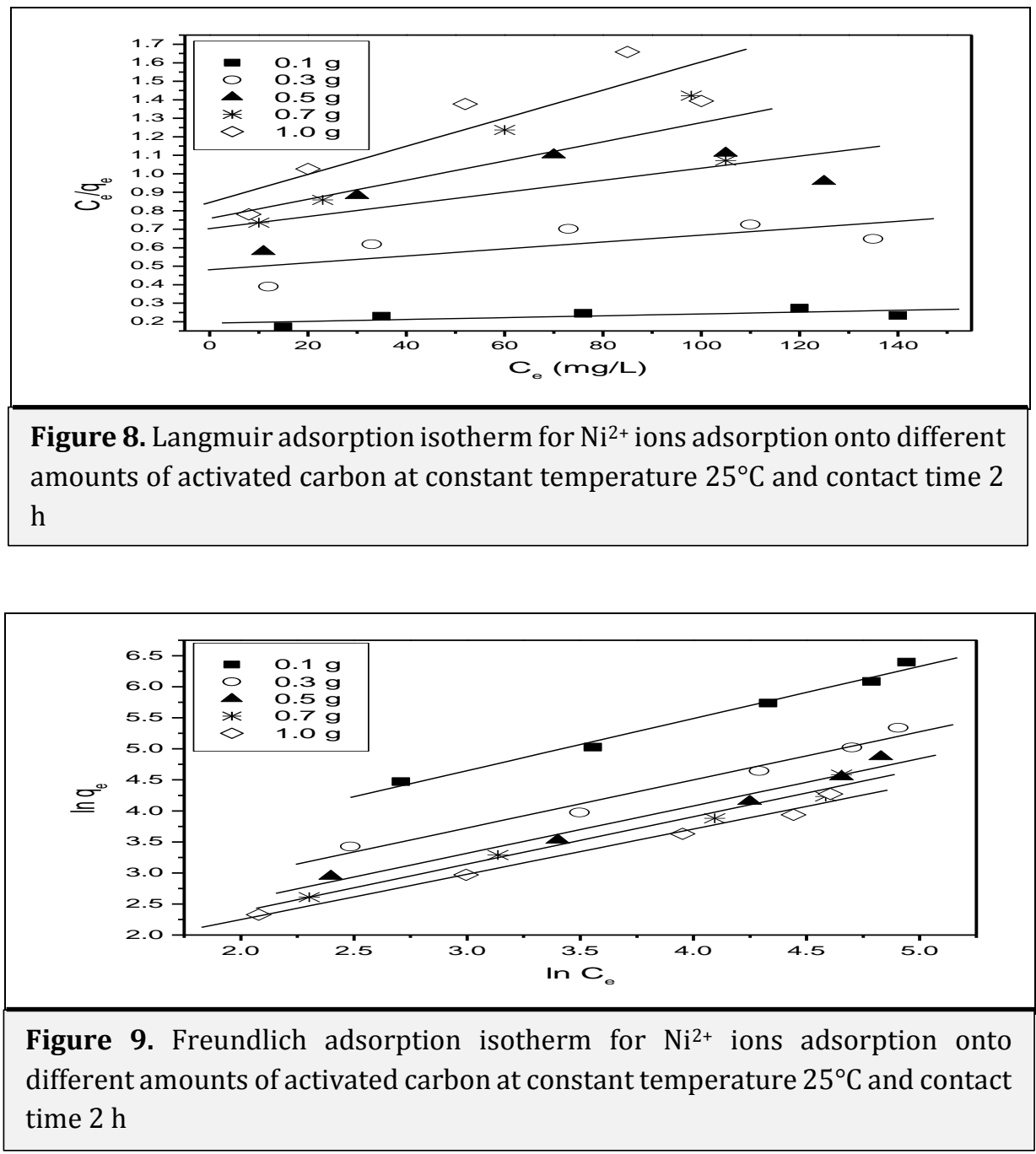

Table 2. Langmuir and Freundlich isotherm for the adsorption of $\mathrm{Ni}^{2+}$ ions onto different doses of activated carbon at constant temperature $\left(25^{\circ} \mathrm{C}\right)$.

\begin{tabular}{c|ccccccc}
\hline \multirow{2}{*}{$\begin{array}{c}\text { Adsorbent } \\
\text { Activated Carbon(g/250mL) }\end{array}$} & \multicolumn{2}{|c|}{ Langmuir Isotherm constants } & \multicolumn{3}{|c}{ Freundlich Isotherm constants } \\
$\mathbf{q m a}$ & $\mathbf{m g} / \mathbf{g})$ & $\mathbf{b} \mathbf{( L / m o l )}$ & $\mathbf{R}^{\mathbf{2}}$ & $\mathbf{K F} \mathbf{( m g / g )}$ & $\mathbf{n}$ & $\mathbf{R}^{\mathbf{2}}$ \\
\hline 0.1 & 77 & $2.8 \times 10-2$ & 0.911 & 8.39 & 1.189 & 0.994 \\
0.3 & 84 & $3.8 \times 10-3$ & 0.889 & 4.12 & 1.290 & 0.991 \\
0.5 & 94 & $4.61 \times 10-3$ & 0.886 & 2.80 & 1.309 & 0.998 \\
0.7 & 193 & $6.8 \times 10-3$ & 0.872 & 2.34 & 1.308 & 0.998 \\
1 & 201 & $8.99 \times 10-3$ & 0.875 & 2.21 & 1.369 & 0.993 \\
\hline
\end{tabular}




\section{Thermodynamic parameters}

The determination of thermodynamic parameters has a great importance to evaluate spontaneity and heat change for the adsorption reaction. The apparent equilibrium constant (Kc) of the adsorption is defined as:

$\mathrm{Kc}=\mathrm{CAe} / \mathrm{Ce}$

The standard Gibb's energy was evaluated by:

$\Delta \mathrm{G}^{\circ}=-\mathrm{RT} \ln \mathrm{Kc}$

Where $\mathrm{R}$ is the ideal gas constant (8.314 J mol-1K-1) and $\mathrm{T}$ is the temperature $(\mathrm{K})$.

Where CAe and Ce (both in $\mathrm{mg} / \mathrm{L}$ ) are the equilibrium concentrations for $\mathrm{Ni}^{2+}$ ions onto the sorbent and in the solution, respectively. In this case, the activity should be used instead of concentration in order to obtain the standard thermodynamic equilibrium constant (Kc) of the adsorption system.

$\ln K c=-\Delta \mathrm{H}^{\circ} / \mathrm{RT}+\Delta \mathrm{S}^{\circ} / \mathrm{R}$

The plot of $\ln \mathrm{Kc}$ as a function of 1 / T yields a straight line is shown on Figures 10, 11 from which $\Delta \mathrm{H}^{\circ}$ and $\Delta \mathrm{S}^{\circ}$ can be calculated from the slope and intercept, respectively.

The negative values of $\Delta G^{\circ}$ at all temperatures $\left(25,30,35\right.$ and $\left.40{ }^{\circ} \mathrm{C}\right)$ indicate the spontaneous nature of the adsorption of $(50,100,200,300$ and 400 $\mathrm{mg} / \mathrm{L}$ ) of $\mathrm{Ni}^{2+}$ onto $0.5 \mathrm{~g} / 250 \mathrm{~mL}$ of activated carbon. The change of the standard free energy decreases with increasing temperatures regardless of the nature of adsorbent. This indicates that a better adsorption is actually obtained at higher temperature. It has been reported that, $\Delta G^{\circ}$ values up to $-20 \mathrm{~kJ} / \mathrm{mol}$ are consistent with electrostatic interaction between sorption sites and the metal ion (physical adsorption), while $\Delta \mathrm{G}^{\circ}$ values more negative than $-40 \mathrm{~kJ} / \mathrm{mol}$ involve charge sharing or transfer from the surface to the metal ion to form a coordinate bond (chemical adsorption). The $\Delta \mathrm{G}^{\circ}$ values obtained in this study for $\mathrm{Ni}^{2+}$ ions are <-10 kJ/mol, which indicates that physical adsorption was the predominant mechanism in the sorption process [13]. The positive value of $\Delta \mathrm{H}^{\circ}$ suggests the endothermic nature of adsorption. The positive value of $\Delta \mathrm{S}^{\circ}$ shows the increased randomness at the solid/solution interface during the adsorption process. Table 3 summarizes the values of these thermodynamic properties. 


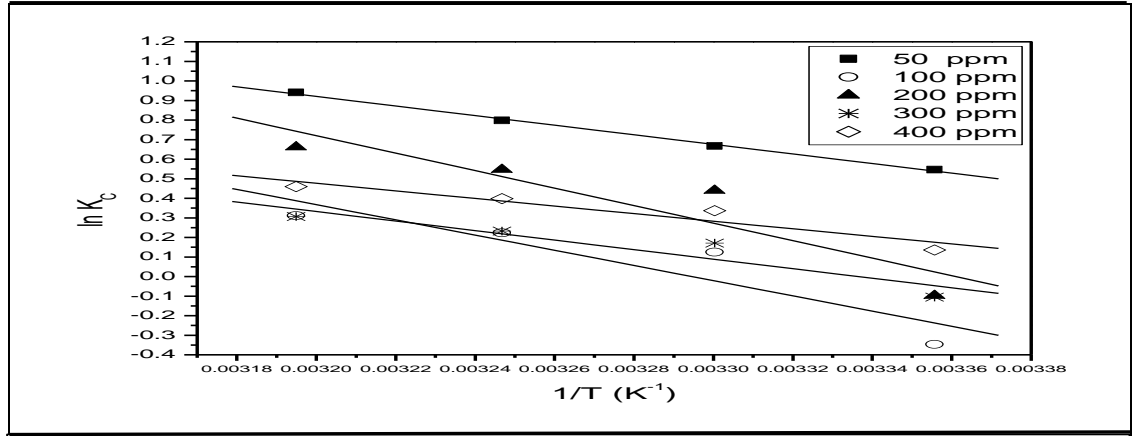

Figure 10. A plot of $\ln \mathrm{KC}$ versus $1 / \mathrm{T}$ for $\mathrm{Ni}^{2+}$ ions adsorption onto activated carbon for different initial $\mathrm{Ni}^{2+}$ concentrations at constant adsorbent dose: $0.5 \mathrm{~g} / 250 \mathrm{~mL}$

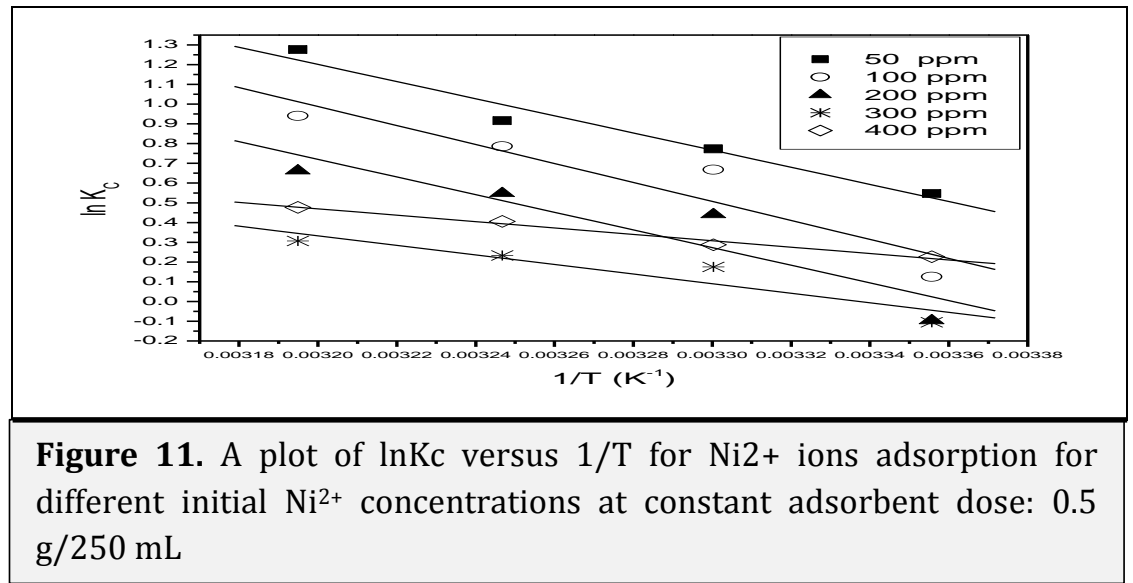

Table 3. Thermodynamic parameters for different concentrations of $\mathrm{Ni}^{2+}$ ions onto activated carbon olive stone

\begin{tabular}{|c|c|c|c|c|c|c|c|}
\hline \multirow[b]{2}{*}{ Adsorbent } & \multirow[b]{2}{*}{ Co (mg/L) } & \multirow[b]{2}{*}{$\begin{array}{c}\Delta H^{\circ} \\
\text { (kj mol- } \\
\text { 1) }\end{array}$} & \multirow[b]{2}{*}{$\begin{array}{c}\Delta S^{\circ} \\
(\mathrm{j} \mathrm{mol-1K}- \\
1)\end{array}$} & \multicolumn{4}{|c|}{$\Delta G^{\circ}(\mathrm{kj} \mathrm{mol}-1)$} \\
\hline & & & & $25^{\circ} \mathrm{C}$ & $30^{\circ} \mathrm{C}$ & $35^{\circ} \mathrm{C}$ & $40^{\circ} \mathrm{C}$ \\
\hline Activated carbon & 50 & 20.4 & 73 & -1.1 & -1.5 & -1.8 & -2.2 \\
\hline Activated carbon & 100 & 32 & 106 & -0.1 & -0.2 & -0.4 & -0.9 \\
\hline Activated carbon & 200 & 35 & 120 & -0.6 & -0.8 & -1.2 & -2.3 \\
\hline Activated carbon & 300 & 21 & 67 & -0.2 & -0.3 & -0.4 & -0.7 \\
\hline Activated carbon & 400 & 16 & 55 & -0.6 & -0.7 & -1.1 & -1.2 \\
\hline
\end{tabular}

\section{Conclusion}

Through this experimental study, it has been shown that the activated carbon olive stone can be used as a free and adsorbent material for the removal of $\mathrm{Ni}^{2+}$ from aqueous solution. The effect of various parameters such as contacting time, solution $\mathrm{pH}$, initial concentration, temperature, and adsorbent dose has been investigated. The isotherm study has indicated that for $\mathrm{Ni}^{2+}$ the adsorption onto olive stones both 
the two models Langmuir and Freundlich can be equally used. The kinetic study has shown that the adsorption process is of the second order and the rate constants have been determined .The thermodynamic study has shown that the adsorption process is spontaneous, since the calculated Gibbs free energy values are negative.

\section{References}

[1]. R.A. Wuana, F.E. Okieimen, Int. Sch. Res. Net., 2011, 2011, 1-20.

[2]. S. Babel, T.A. Kurniawan, J. Hazard. Mater., 2003, 97, 219-243

[3]. (a) U. Förstner, G.T.W. Wittmann, Metal pollution in the aquatic environment. Springer Science, Business Media, 2012, p. 332. (b) Alomá, I., Martín-Lara, M.A., Rodríguez, I.L., Blázquez, G., Calero, M., J. Taiwan Instit. Chem. Eng., 2012, 43, 275281.

[4]. A. Figoli, A. Cassano, A. Criscuoli, M.S.I. Mozumder, M.T. Uddin, M.A. Islam, E. Driolo, Water Res., 2010, 44, 97-104.

[5]. T.P. Coogan, D.M. Latta, E.T. Snow, M. Costa, A. Lawrence, Crit. Rev. Toxicol., 1989, 19, 341-384.
[6]. IARC Monographs on the evaluation of carcinogenic risks to humans, Vol.49 Chromium, nickel andwelding Lyon, 1990. [7]. Norseth T., Nickel, in Handbook on the Toxicology of Metals, Volume II: Specific Metals, 2nd edn. Friberg, L., Nordberg, G., Vouk, V., Eds., Elsevier Science Publishers, Amsterdam, 1986.

[8]. H. Savolainen. Biochemical and clinical aspects of nickel toxicity; Reviews on environmental health, 1996, 11, 167-173.

[9]. Roy, J. Bhattacharya, Nanotechnology in industrial wastewater treatment. IWA Publishing, 2015, page 14.

[10]. Davis, Joseph R; Handbook Committee, ASM International "Nickel, cobalt, and their alloys". 2000, p. 354. ISBN 978-0-87170685-0.

[11]. H. Nakagowa, M. Tabata, Y. Morikawa, M. Senma, Y. Kitagawa, S. Kawano, T. Kido, Arch. Environ. Health, 1990, 45, 283-287.

[12]. Y.S. Ho, G. Mcaky, Water Res., 2000, 34, 735-742.

[13]. I. Tsibranska, E. Hristova, Bulg. Chem. Commun., 2011, 43, 370-377.

How to cite this manuscript: Abdel-Moneum Ahmed, Alaa Ali, Ahmed Hosny Ghazy*, Adsorption Separation of Nickel from wastewater by using Olive Stones, Adv. J. Chem. A, 2019, 2(1), 79-93. 